\title{
Some Theoretical and Applied Aspects of the Oceanic Bioluminescence Registration from Space
}

\author{
Yuriy Tokarev, Vladimir Vasilenko, Olga Mashukova \\ Biophysical Ecology Department, Federal State Budget Institution of Science, “A.O. Kovalevsky Institute of Marine Biological \\ Research, RAS”, Sevastopol, Russia \\ Email: y.tokarev@gmail.com
}

How to cite this paper: Tokarev, Y., Vasilenko, V. and Mashukova, O. (2017) Some Theoretical and Applied Aspects of the Oceanic Bioluminescence Registration from Space. Advances in Bioscience and Biotechnology, 8, 283-294.

https://doi.org/10.4236/abb.2017.89021

Received: August 11, 2017

Accepted: September 10, 2017

Published: September 13, 2017

Copyright $\odot 2017$ by authors and Scientific Research Publishing Inc. This work is licensed under the Creative Commons Attribution International License (CC BY 4.0).

http://creativecommons.org/licenses/by/4.0/

\begin{abstract}
The analysis of the surface bioluminescence in the World Ocean registration problems for the purposes of its regions ecological express-monitoring and evaluation of the plankton algae spatial distribution at night time by the existing space systems has been proposed. The connection of the plankton community characteristics with a bioluminescent potential (BP) in the euphotic layer and a possibility to evaluate $\mathrm{BP}$ according to bioluminescence intensity in the near-surface layer of $0-10 \mathrm{~m}$ has been demonstrated. It has been shown that with complete correspondence with the vertical structure in the plankton community at the dark time bioluminescence intensity in $0-10$ $\mathrm{m}$ layer exceeds the same in $60-70 \mathrm{~m}$ layer for one and a half orders and practically determines BP in $0-100 \mathrm{~m}$ layer. Peculiarities of the plankton organisms light emission, important for the oceanic bioluminescence registration with the space means of observation are under discussion. Equation for calculation of the measured by the space device sea luminescence level and volume of the bioluminescence intensity in the surface layer of the World Ocean, which can be registered due to modern technical means of the space systems has been corrected. The conclusion has been done that on the base of the space data about spatial and temporal phytoplankton distribution and bioluminescence "in situ" measurements it is possible to create regional algorithms for transition from numerical estimations of the phytoplankton (chlorophyll "a") to the day time bioluminescent potential and solution of inverse tasks at night time.
\end{abstract}

\section{Keywords}

Plankton, Sea Bioluminescence, Space Systems 


\section{Introduction}

The tasks of making more effective and operative control of marine environment condition demanded together with traditional modes of monitoring to use methods of operative oceanography, including remote sounding of marine surface [1]-[8]. Remote methods have great advantage if compared with contact measurements methods, as they can be conducted with the help of the space means and aircrafts and contain express-information about the state of the plankton community at the near-surface layer on great water areas. Today they know already numerous successful experiments on usage of the space measurements for express evaluation of the spatial and temporal dynamics in the surface layer water color, wind waves kinetics, distribution of chlorophyll "a", mineral suspension and organic substance solution, pollution sources in different regions etc. [9]-[16]. Remote methods of operative oceanography play for sure a decisive role in biological and ecological investigations of the World Ocean in the 21st century [1].

In comparison with obvious successes in the studies of the mentioned above ocean physical and biological characteristics by the methods of the space sounding achievements in the studies by such methods of the near-surface sea waters bioluminescence are quite moderate. But they could increase considerably an effect of using ocean space monitoring, making it more functional and for a time of the twenty-four hours regime. That is why theoretical basing and demonstration of the oceanic bioluminescence space registration real possibilities with the purpose of considerable increase in effective usage of the modern means for operative monitoring of the ocean surface and making its functional load higher are the main objectives of the given work.

\section{Materials and Methods}

Bioluminescence-an organism electro-magnetic irradiation in the visible spectrum field-is an important element of the World ocean pelagic communities functioning [17] [18] [19] [20]. The studies of bioluminescence characteristics and elucidation of their connection with the plankton habitants characteristics are being conducted in different countries for about 70 years [19] [21]. For this period, great material has been accumulated, which permitted together with colleagues from different countries to create a base of the World Ocean bioluminescence data [22] [23].

This database permitted to determine interconnections between bioluminescence intensity and the plankton community indices, gradients of temperature and salinity and to trace spatial-temporal bioluminescence field changeability at the regional and synoptic scale, to reveal physical and biological factors, causing these changeability, to evaluate an influence of the anthropogenic press on the biota functional condition etc. [21] [24] [25].

Intensity of bioluminescence was measured using the IBSS-made bathyphotometers [8] [19] with multiple vertical (10 - 30) profiling of the upper 100-metre 
layer, with 3 minute intervals between soundings. A special device was employed, which limited the astronomical component of luminescence and provided a constant level of mechanical stimulation of bioluminescents. Profiles were conducted with a speed of $1 \mathrm{~m} \mathrm{sec}^{-1}$. Measurements of bioluminescence of plankton organisms began 2 hours after sunset. This permitted the exclusion of the influence of daylight on the rhythm of light emission of plankton bioluminescents and their vertical migration. Together with bioluminescence measurements, temperature of the studied layer, speed of drift of the vessel, force and direction of wind were taken.

Phytoplankton was sampled with a rosette of 10-1 water bottles, fixed $1 \mathrm{~m}$ higher than the bathyphotometer, from intense bioluminescence layers and standard horizons. The water samples were filtered with $0.45 \mu \mathrm{m}$ pore diameter filters, after which the numbers of testaceous dinophyte algae were counted. These dinoflagellates are the most important bioluminescence component of marine phytoplankton [21]. Means of data of bioluminescence intensity and average number of dinoflagellates, for the layer $0-100 \mathrm{~m}$, were calculated and coefficients of correlation and linear regressions $(\mathrm{Y}=\mathrm{bX}+\mathrm{a})$ of the dependence "bioluminescence intensity (Y) - number of dinoflagellates (X)" determined.

These materials made a base for a conception we accepted about possibility to register oceanic bioluminescence with the help of the space systems that we give in this article.

\section{Results}

Earlier we have shown that bioluminescence intensity in tropic waters was closely connected with values of plankton biomass and fluorescence of chlorophyll "a" [26] (Figure 1). To compare the trends of these characteristics we used our own data and published materials of other researchers [13] [18] [22] [26]. The most obvious under visual comparison of these fields in Atlantic Ocean is the fact that bioluminescence trends similar the trends of the mesozooplankton biomass and chlorophyll "a" fluorescence (Figure 1). This proves prevailing contribution of the given plankton fractions into bioluminescence field formation, which is confirmed by close correlative links of bioluminescence with biomass and abundance of plankton and first of all of dinophyte algae [19].

Such level of connection is observed everywhere, including such peculiar in thermochaline parameters of water masses regions as Black and Marmara seas, which is seen from materials of the stations fulfilled in 35 and 53 cruises of $R / V$ "Professor Vodyanitsky" and in the cruise of Turkish R/V "Bilim" (Table 1). The given in the Table 1 magnitudes of correlation coefficients $(\mathrm{p}<0.05)$ and equations of linear regression coincide with the same for the other regions of the World ocean [19]. This important for comparison of the space data on spatial and temporal distribution of phytoplankton and bioluminescence, working out an algorithm for conversion numerical phytoplankton evaluations (chlorophyll "a") to the bioluminescent potential and for solution of inverse task. 


\section{Discussion}

The efforts in measuring bioluminescence by the remote methods were undertaken many times, including those with laser exciting [27] [28] [29]. The essence of these methods is simple: mounted on the airplane or space carrier lidar emit an impulse of coherent radiation in optic range, which gets into water and while distributing it excites bioluminescence. Bioluminescence light signal through water surface and atmosphere gets to accepting device-photomultiplier (PMP), then on after transformation signal is placed into board computer for storage and further processing.

The most complete theoretical grounds for possibility of remote registration of the surface layer bioluminescence is given in the work [30]. The author calculated energetic characteristics of the bioluminescence light field at the planned height over the ocean surface. On the base of the literature data he gave
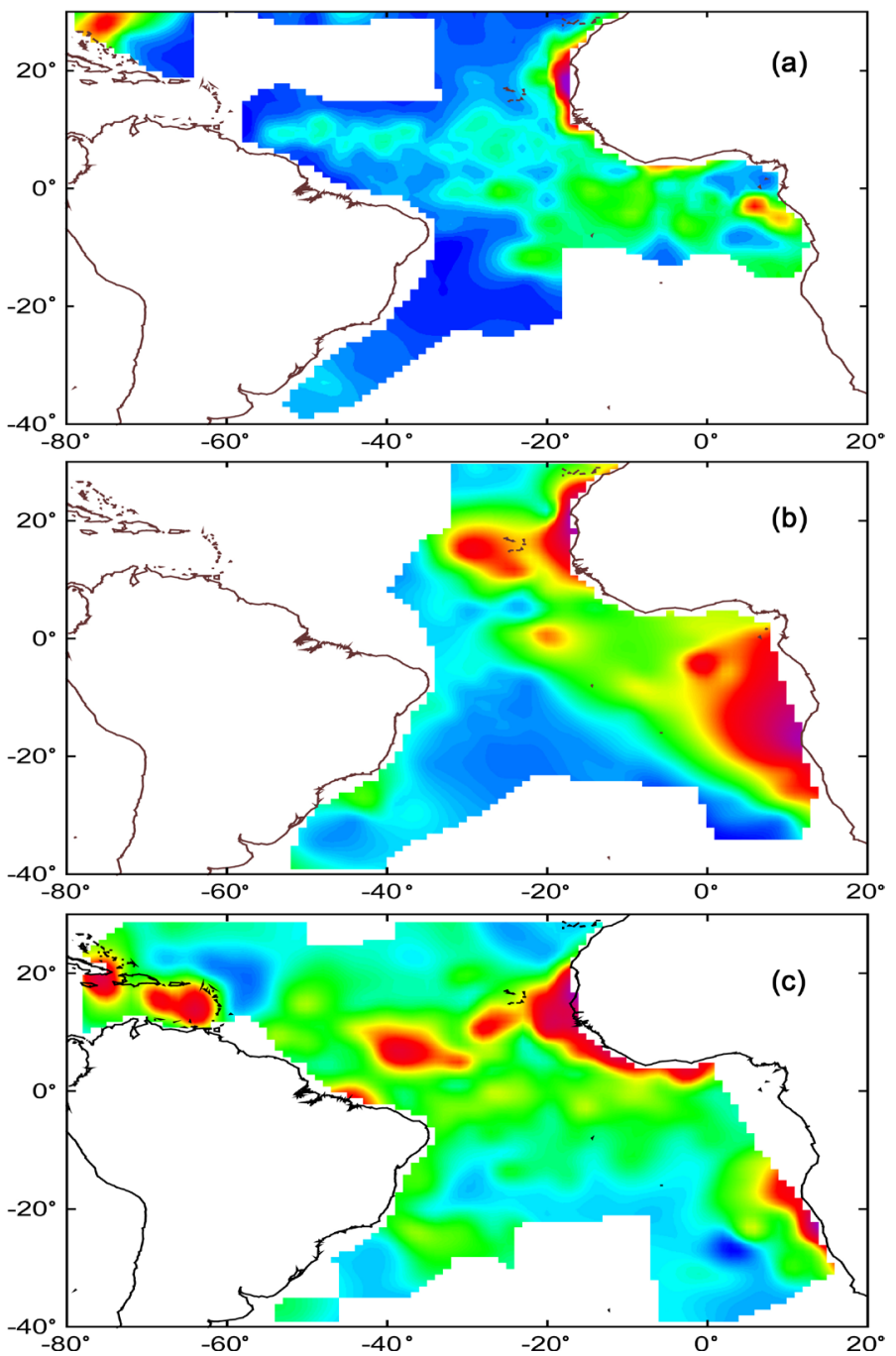

Figure 1. The Atlantic ocean bioluminescent field (b) and plankton community components: (a) phytoplankton (chlorophyll "a" and mesozooplankton (c). Increase in parameters volumes corresponds to the spectrum color gamma (from blue to red) color gamma (from Piontkovski, Tokarev, Bitukov, Williams \& Kiefer, 1997). 
Table 1. Correlation between bioluminescence and number of the total phytoplankton at the stations in the Black (4824, Bs2) and Marmara (Ms5s) seas.

\begin{tabular}{|c|c|c|c|c|c|}
\hline Region & Bearings & $\begin{array}{l}\text { Horizon } \\
(\mathrm{m})\end{array}$ & $\begin{array}{l}\text { Bioluminescence } \\
\text { intensity } \\
\left(10^{-12} \mathrm{~W} \cdot \mathrm{cm}^{-2} \cdot \mathrm{l}^{-1}\right)\end{array}$ & $\begin{array}{l}\text { Phytoplankton } \\
\text { abundance } \\
\left(\text { cell. } \cdot^{-1}\right)\end{array}$ & $\begin{array}{l}\text { Equation of regression } \\
\text { and correlation } \\
\text { coefficient }(\mathrm{r})\end{array}$ \\
\hline \multirow{11}{*}{$\begin{array}{c}4824 \\
\text { (The Black } \\
\text { sea) }\end{array}$} & \multirow{11}{*}{$\begin{array}{l}44.16 \text { N.Lat. } \\
31.51 \text { O.Lon. }\end{array}$} & 1 & 927 & 918,621 & \multirow{11}{*}{$\begin{array}{c}\mathrm{y}=277.2+0.028 \mathrm{x} \\
\mathrm{r}=0.851\end{array}$} \\
\hline & & 5 & 2729 & 951,420 & \\
\hline & & 10 & 2191 & 930,240 & \\
\hline & & 15 & 2809 & 987,698 & \\
\hline & & 20 & 2797 & 988,950 & \\
\hline & & 25 & 1971 & 897,600 & \\
\hline & & 30 & 1628 & 307,000 & \\
\hline & & 35 & 1840 & 104,000 & \\
\hline & & 40 & 191 & 82,498 & \\
\hline & & 45 & 0 & 40,258 & \\
\hline & & 50 & 0 & 40,800 & \\
\hline \multirow{11}{*}{$\begin{array}{c}\text { Bs2 } \\
\text { (The Black } \\
\text { Sea) }\end{array}$} & \multirow{11}{*}{$\begin{array}{l}41.57 \text { N.Lat. } \\
29.36 \text { O.Lon. }\end{array}$} & 1 & 3000 & 308,101 & \multirow{11}{*}{$\begin{array}{c}\mathrm{y}=-143.1+0.069 x \\
\mathrm{r}=0.759\end{array}$} \\
\hline & & 10 & 2223 & 414,552 & \\
\hline & & 15 & 3099 & 378,033 & \\
\hline & & 20 & 3423 & 429,894 & \\
\hline & & 25 & 3852 & 250,818 & \\
\hline & & 30 & 2604 & 70,359 & \\
\hline & & 40 & 147 & 85,443 & \\
\hline & & 50 & 39 & 51,008 & \\
\hline & & 60 & 48 & 64,078 & \\
\hline & & 70 & 45 & 67,660 & \\
\hline & & 85 & 36 & 45,600 & \\
\hline \multirow{9}{*}{$\begin{array}{c}\text { Ms5c } \\
\text { (Marmara } \\
\text { sea) }\end{array}$} & \multirow{9}{*}{$\begin{array}{l}\text { 40.46 N.Lat. } \\
\text { 29.05 O.Lon. }\end{array}$} & 1 & 1899 & 308,177 & \multirow{9}{*}{$\begin{array}{c}\mathrm{y}=217.4+0.064 \mathrm{x} \\
\mathrm{r}=0.77\end{array}$} \\
\hline & & 10 & 1980 & 487,711 & \\
\hline & & 15 & 1410 & 72,140 & \\
\hline & & 20 & 3 & 51,805 & \\
\hline & & 25 & 0.5 & 25,802 & \\
\hline & & 40 & 0.5 & 30,604 & \\
\hline & & 45 & 0.5 & 39,201 & \\
\hline & & 50 & 0.5 & 55,200 & \\
\hline & & 55 & 0.5 & 43,851 & \\
\hline
\end{tabular}

estimation of voluminous density of the bioluminescent sources for different types of organisms. Having solved corresponding tasks of theoretical optics 
(transfer of radiation) he evaluated relation bioluminescent signal-astronomic background under the given threshold sensitivity of the registering device.

But to our opinion, the authors of this paper had not taken into consideration a number circumstance, to a great extent determining possibilities of the bioluminescence field space registration. First of all to the contrary to hydro-optic field described by physical laws of energy transfer, characteristics of bioluminescence (intensity, scattering indicatrix, weakening during distribution, etc.) depend on the action of many factors, first of all, biological: composition of organisms, which generate light flashes of different duration and amplitude; their physiological state; endogenous and exogenous luminescence diurnal rhythms; spatial anisotropy of light emitting organs etc., not elucidated in many aspects by the present time.

The second disputable data are given when analyzing the data on energetic characteristics of bioluminescents light emission. For example, energy of the flash of mass plankton bioluminescent in the Black sea Noctiluca scintillans (Macartney) Kofoid \& Swezy is taken in calculations as $0.1 \times 10^{-6} \mathrm{~W} \cdot \mathrm{cm}^{-2}(3.0 \times$ $10^{6}$ phot $\left.\cdot \mathrm{s}^{-1}\right)$. But it is known that luminescence intensity in plankton bioluminescents depends on development stage, season, day time, functional state and can change for several orders of magnitudes [21] [24]. For example, in $N$. scintillans flash amplitude can change from $1.0 \times 10^{-7} \mathrm{~W} \cdot \mathrm{cm}^{-2}\left(3.0 \times 10^{6}\right.$ phot $\left.\cdot \mathrm{s}^{-1}\right)$ to $1.0 \times 10^{-3} \mathrm{~W} \cdot \mathrm{cm}^{-2}\left(3.15 \times 10^{10}\right.$ phot $\left.\cdot \mathrm{s}^{-1}\right)$, i.e. for $3-4$ orders [21].

It is not quite clear also in the paper, whether author took into consideration difference in spectral characteristics of the registering space devices and spectral composition of the bioluminescence field in the region of measurements. But as we have shown difference in the bioluminescence field spectral characteristics and those of the board registering devices, regional specificity of the plankton bioluminescents species composition and time (season, ontogenetic) changeability of their light emission spectral characteristics predetermine considerable difference in the amplitude indices of the registered characteristics [21] [31].

A number of questions are caused by the used method of bioluminescence registration with the help of satellites. Really first attempts to stimulate bioluminescence by the source of coherent light with wave length $560+39 \mathrm{~nm}$ revealed discrepancies in the results obtained. In particular, it is not clear whether organism luminescence (Pyrocystis lunula Schütt, F. (1896)) is a reaction to laser impulse or excitement takes place due to ultrasound, appearing under interaction of laser ray with water and resulting in heating and heat widening of environment in the field of taking up the penetrating radiation [32].

It is necessary also to mark that under satellite registration of the bioluminescence in the World Ocean coastal zone there occur many additional complexities. For example, sea water in a number of regions contains soluble non-organic and organic substances, including oil hydrocarbons, as well as it undergo influence of the acid rains which change processes of solution, heat exchange, indices of its albedo etc. That is why penetrating into water laser ray stimulates not only 
bioluminescence but also causes fluorescence of these pollutions. Such "pollutant fluorescence" has wide spectrum (400 - $750 \mathrm{~nm}$ ) with two maximums of radiation, close to 440 and $580 \mathrm{~nm}$, which can shift depending on the type of pollutants and their concentration, remaining practically constant under any length of excitement wave. As pigments of the phytoplankton are also fluorescent this creates considerable obstacle for using proved methodics of the satellite ocean sounding for studying bioluminescence.

The first remote observation of the spontaneous surface oceanic bioluminescence at $15,400 \mathrm{~km}^{2}$ square has been fulfilled in Indian Ocean by American meteorology satellite from the height of $800 \mathrm{~km}$ in a regime of "postponed time" [33]. Luminescence was observed during three nights and the authors consider that only bacteria are able to create such low - level spontaneous light emission, as they emit light constantly and their luminescence can continue during many days [31].

It is known that bioluminescence intensity of characteristic for the given region bacteria Vibrio harveyi Johnson and Shunk, 1936 makes $10^{-3} \mathrm{phot} \cdot \mathrm{s}^{-1} \cdot \mathrm{cl}^{-1}$, and maximum of the spectral emission $-490 \mathrm{~nm}$ with half-width of emission of $70 \mathrm{~nm}$ [34]. As a detector of light emission in the satellite used PMP with optic range of $470-950 \mathrm{~nm}$. For better visual contrast between surface bioluminescence and surrounding light background satellite data were processed with a program, permitting to register minimal signal of a level $1.8 \times 10^{-4} \mathrm{~W} \cdot \mathrm{m}^{-2} \cdot \operatorname{ster}^{-1}$. Then a share of the registered light emission of "milk sea" (due to non-coincidence of the bioluminescence emission spectrum and spectral sensitivity of the light detector of satellite) could be determined by formula [33]:

$$
F=\frac{\int_{\lambda=0}^{\infty} B_{\lambda} T_{\lambda} \theta \Phi_{\lambda} d_{\lambda}}{\int_{\lambda=0}^{\infty} \Phi_{\lambda} d_{\lambda}}
$$

where: $B_{\lambda}$-spectrum of bacteria luminescence;

$\Phi_{\lambda}$-spectral characteristic of luminescence sensor;

$T_{\lambda}$-spectral coefficient of atmosphere radiation;

$\theta$-angle of the satellite optical system vision;

Evaluation of bacteria colony minimal population $\left(\mathrm{C}_{\min } \cdot \mathrm{cl} \cdot \mathrm{m}^{-2}\right)$ at the level of minimal signal $\mathrm{C}_{\min } \cdot 1.8 \times 10^{-4} \mathrm{~W} \cdot \mathrm{m}^{-2} \cdot \mathrm{ster}^{-1}$ was made on the base of equation [33]:

$$
C_{\min }=\pi L_{\min } \frac{2 \lambda}{h c w}
$$

where: $\lambda$-length of luminescence wave;

$h$-Plank constant;

c-light rate in vacuum;

$w$-level of photon emitted by cell.

On the base of formulas (1) and (2) for registration of minimal bioluminescence by the satellite light detector they have determined bacteria cells concentration, 
which must correspond to $\mathrm{C}_{\min }=2.8 \times 10^{8} \mathrm{cl} \cdot \mathrm{cm}^{-2}$. Considering given above light energy (W) of one bacteria bioluminescent signal under modern technical possibilities of space devices can be registered if its minimal level exceeds $\mathrm{F}_{\min }=$ $\mathrm{W} \cdot \mathrm{C}_{\min }=2.8 \times 10^{15} \mathrm{phot} \cdot \mathrm{s}^{-1} \cdot \mathrm{m}^{-2}$ [33]. But to our opinion one should consider some conditionality of such suppositions, as such low levels of light emission with duration of bioluminescence many times exceeding $1 \mathrm{c}$ are characteristic for spontaneous bioluminescence ("glow") of dinoflagellates [31]. Moreover formula (1) for calculation of a share of the registered luminescence of "milk sea" is not quite correct. And besides, even under condition that in the given region surface luminescence is generated exclusively by bacteria, on the base of the given in the works [30] [33] prerequisites and boundary conditions it must look like the following:

$$
F=\frac{\int_{\lambda=0}^{\infty} B_{\lambda} T_{\lambda}(\theta) \Phi_{\lambda} d_{\lambda}}{\int_{\lambda=0}^{\infty} B_{\lambda} d_{\lambda}}
$$

In such case concentration of bacterial cells, corresponding to minimal level of the bioluminescent signal in $1.8 \times 10^{-4} \mathrm{~W} \cdot \mathrm{m}^{-2} \cdot \mathrm{ster}^{-1}$ will considerable differ (to the side of increase) from the given in the work of American colleagues [33].

Having analyzed the given in the database "The database on the bioluminescence field of the World Ocean" materials and having compared them with the given in the works [23] and [33] threshold sensitivity of the satellite sensors we give in Table 2 regions of the World Ocean where surface bioluminescence just today can be correctly measured. And their bioluminescence field energy is given in two sizes, most widely used in literature sources: $\mathrm{W} \cdot \mathrm{cm}^{-2} \cdot \mathrm{l}^{-1}$ and phot $\cdot \mathrm{s}^{-1} \cdot \mathrm{l}^{-1}$. Transition coefficient (from $10^{-12} \mathrm{~W} \cdot \mathrm{cm}^{-2} \cdot \mathrm{l}^{-1}$ to phot $\cdot \mathrm{s}^{-1} \cdot \mathrm{l}^{-1}$ ) has been received by us under intercalibration of the hydrobiophysical complex "Salpa" and American apparatus "Hidex" in 1996 during international expedition on board R/V "Bilim" (Turkey) in the Black and Marmara seas [16].

Thus, today on the base of the space data on spatial and temporal phytoplankton distribution and synchronous measurements "in situ" of bioluminescence it is possible to create regional algorhythms of transition from quantitative evaluations of phytoplankton (chlorophyll "a") to bioluminescent potential at the day time and solution of inverse tasks at night. The materials of above mentioned database on the World Ocean bioluminescence and successful examples of working out regional algorhythms for transition satellite measurements of chlorophyll "a" to biological and ecological parameters of the euphotic layer for White, Okhotsk and Black seas can serve as ground for this [10] [35].

\section{Conclusions}

1) The level of the World Ocean surface layer bioluminescence, which can be registered with modern technical possibilities of space systems, has been determined. 
Table 2. The World Ocean regions with a level of surface bioluminescence, enough for registration by modern space systems.

\begin{tabular}{|c|c|c|c|}
\hline $\begin{array}{l}\text { Bioluminescence intensity } \\
\qquad\left(10^{-12} \mathrm{~W} \cdot \mathrm{cm}^{-2} \cdot \mathrm{l}^{-1}\right)\end{array}$ & $\begin{array}{l}\text { Bioluminescence intensity } \\
\left(\times 10^{15} \mathrm{phot} \cdot \mathrm{m}^{-3} \cdot \mathrm{s}^{-1}\right)\end{array}$ & Region & Bearings \\
\hline 2500.00 & 3.75 & Mediterranean & $\begin{array}{l}35.05 \text { N.Lat.; } \\
04.54 \text { W.Lon. }\end{array}$ \\
\hline 2200.00 & 3.3 & & $\begin{array}{l}35.40 \text { N.Lat.; } \\
6.50 \text { W.Lon. }\end{array}$ \\
\hline 2000.00 & 3.0 & Atlantic Ocean & $\begin{array}{l}\text { 12.39 N.Lat.; } \\
\text { 36.6 W.Lon. }\end{array}$ \\
\hline 4500.00 & 6.75 & Black sea & $\begin{array}{l}\text { 41.25 N.Lat.; } \\
29.21 \text { O.Lon. }\end{array}$ \\
\hline 3500.00 & 5.25 & & $\begin{array}{l}36.05 \text { N.Lat.; } \\
07.07 \text { W.Lon. }\end{array}$ \\
\hline 2700.00 & 4.05 & Mediterranean & $\begin{array}{l}\text { 36.43 N.Lat.; } \\
\text { 18.46 W.Lon. }\end{array}$ \\
\hline 5000.00 & 7.5 & Black sea & $\begin{array}{l}42.56 \text { N.Lat.; } \\
31.09 \text { O.Lon. }\end{array}$ \\
\hline 5500.00 & 8.25 & & $\begin{array}{l}\text { 25.02 S.Lat.; } \\
\text { 05.27 W.Lon. }\end{array}$ \\
\hline 2100.00 & 3.15 & Atlantic Ocean & $\begin{array}{c}\text { 36.25 S.Lat.; } \\
18.10 \text { W.Lon. }\end{array}$ \\
\hline 2500.00 & 3.75 & & $\begin{array}{l}\text { 44.22 N.Lat.; } \\
34.25 \text { O.Lon. }\end{array}$ \\
\hline 4500.00 & 6.75 & Black sea & $\begin{array}{l}44.15 \text { N.Lat.; } \\
\text { 33.30 O.Lon. }\end{array}$ \\
\hline 2700.00 & 4.05 & Atlantic Ocean & $\begin{array}{l}43.20 \text { N.Lat.; } \\
36.2 \text { W.Lon. }\end{array}$ \\
\hline 3000.00 & 4.5 & & $\begin{array}{l}45.00 \text { N.Lat.; } \\
31.45 \text { O.Lon. }\end{array}$ \\
\hline 4500.00 & 6.75 & & $\begin{array}{l}\text { 44.16 N.Lat.; } \\
\text { 31.51 O.Lon. }\end{array}$ \\
\hline $10,000.00$ & 15.0 & Black sea & $\begin{array}{l}44.06 \text { N.Lat.; } \\
36.19 \text { O.Lon. }\end{array}$ \\
\hline 4000.00 & 6.0 & & $\begin{array}{l}41.34 \text { N.Lat.; } \\
29.20 \text { O.Lon. }\end{array}$ \\
\hline
\end{tabular}

2) On the base of the space data on the spatial and temporal phytoplankton distribution and bioluminescence measurements "in situ", it is possible to create regional algorhythms for reversing from quantitative evaluations of phytoplankton (chlorophyll "a") to bioluminescent potential at the day time and solution of inverse tasks at night.

\section{Acknowledgements}

The authors are grateful to V.F. Juk (scientific worker of KIMBR, RAS), as well as to Yu.B. Belogurova, M.I. Silakov and A. Sergeeva (leading engineers of KIMBR, RAS), for the technical assistance and the statistical treatment of the data and useful comments. 
This work was conducted in the frame of the KIMBR, RAS, State task No. 0828-2014-0016.

\section{References}

[1] Ackleson, S. (2001) Ocean Optics Research at the Start of the 21st Century. Oceanography, 14, 5-8. https://doi.org/10.5670/oceanog.2001.19

[2] Bezgin, A.A. and Urkevich, N.Y. (2016) Modern Satellite Communication Systems and Their Use for Solving Operational Oceanography Problems. Ecological Safety of Coastal and Shelf zones of Sea, 4, 88-92.

[3] Belyaev, M.Yu., Desinov, L.V., Kumakshev, S.A., Sekerzh-Zen'kovich, S.Ya. and Krikalev, S.K. (2009) Identification of a System of Oceanic Waves Based on Space Imagery. Journal of Computer and Systems Sciences International, 48, 110-120. https://doi.org/10.1134/S1064230709010109

[4] Grimes, D.J., Ford, T.E., Colwell, R.R., Baker-Austin, C., Martines-Urtaza, J., et al. (2014) Viewing Marine Bacteria, Their Activity and Response to Environmental Drivers from Orbit. Microbial Ecology, 67, 489-500. https://doi.org/10.1007/s00248-013-0363-4

[5] Gurvich, I.A. and Zabolotskikh, E.V. (2015) Mesoscale Polar Lows over the Eastern Arctic Sector According to Multisensor Satellite Remote Sensing. Modern Problems of the Earth Remote Sensing from Space, 12, 101-112.

[6] Ivanov, V.A., Dikman, V.Z., Efremov, O.I., Zima, V.V., Bolshakov, O.M., et al. (2006) The Modern Methods and Facilities of the Marine Environment Control. ECOSI-Hydrophysics, Sevastopol, $113 \mathrm{pp}$.

[7] Korotaev, G.K. and Eremeev, V.N. (2006) Introduction to the Black Sea Operational Oceanography. ECOSI-Hydrophysica, Sevastopol, 261-283.

[8] Tokarev, Yu.N. and Melnikov, V. (2010) The New Methodology of the Marine Plankton Communities Complex Investigations. Proceedings of the IV International Symposium “Oceans from Space”, Venice, 26-30 April 2010, Publications Office of the European Union, Luxemburg, 225-226.

[9] Belyaev, M.Yu., Desinov, L.V., Karavayev, D.Yu., Sarmin, E.E. and Yurina, O.A. (2015) The Study of Catastrophic Events That May Lead to Environmental Challenges under the Program "Hurricane" Onboard the Russian Segment of the International Space Station. Cosmonautics and Rocket Engineering, 1, 71-79.

[10] Bukin, O.A., Permyakov, M.S., Zenkin, O.L., Burov, D.V. and Salyuk, P.A. (2003) Comparative Analyses of the Chlorophyll-a Concentrations Measured by SeaWiFS and by the Laser Induced in the Sea of Okhotsk. Earth Research from Space, 4, 84-90.

[11] Jerome, J.H., Bukata, R.P. and Miller, J.R. (1996) Remote Sensing Reflectance and Its Relationships to Optical Properties of Natural Waters. International Journal of Remote Sensing, 17, 3115-3155. https://doi.org/10.1080/01431169608949135

[12] Korosov, A.A. and Pozdnyakov, D.V. (2005) Evaluation of the Current State and Modification Trends of the White Sea Primary Production from Remote Sensing Data for the Last Five Years: Methods and Pilot Results. The Study, Sustainable Use and Conservation of Natural Resources of the White Sea. Proceedings of the International Conference, Petrozavodsk, 11-14 October 2004, 165-171.

[13] Longhurst, A., Sathyendranath, S., Platt, T. and Caverhill, C. (1995) An Estimate of Global Primary Production in the Ocean from Satellite Radiometer Data. Journal of Plankton Research, 17, 1245-1271. https://doi.org/10.1093/plankt/17.6.1245 
[14] O’Reilly, J.E., Maritorena, S., Mitchell, S.G., Siegel, D.A., Carder, K.L., et al. (1998) Ocean Color Chlorophyll Algorithms for SeaWiFS. Journal of Geophysical Research, 103, 24930-24953. https://doi.org/10.1029/98JC02160

[15] Pozdnyakov, D.V., Pettersson, L.H., Johannessen, O.M., Lyaskovsky, A.V., Filatov, N.N., et al. (2003) SeaWiFS Maps Water Quality Parameters of the White Sea. International Journal of Remote Sensing, 24, 3-6. https://doi.org/10.1080/01431160210163164

[16] Zabolotskikh, E.V., Mitnik, L.M. and Chapron, B. (2013) New Approach for Severe Marine Weather Study using Satellite Passive Microwave Sensing. Geophysical Research Letters, 40, 3347-3350. https://doi.org/10.1002/grl.50664

[17] Bityukov, E.P., Vasilenko, V.I. and Tokarev, Y.N. (1978) Concerning Spectral Composition of the Bioluminescence Field in the Black and Mediterranean Seas and in the Atlantic Ocean. Biologiya morya, 47, 40-48.

[18] Gitelson, I.I., Levin, L.A., Rudyakov, J.A. and Utyushev, R.N. (1997) The Estimation of Sea Bioluminescence by Mesozooplankton Biomass Distribution in the Upper Layer of the Central Atlantic. In: Hastings, J.W., Kriska, L.J. and Stanley, P.E., Eds., Bioluminescence and Chemiluminescence, Molecular Reporting with Photons, Proceedings of 9 th International Symposium, J. Willey and Sons, Chichester, 165-168.

[19] Tokarev, Y.N. (2006) Basin of Hydrobionts Biophysical Ecology. ECOSI Hydrophysics, Sevastopol, $342 \mathrm{p}$.

[20] Tokarev, Y.N., Bityukov, E.P., Vasilenko, V.I., Evstigneev, P.V., Borodin, D.N., et al. (2003) Plankton Bioluminescents Specific Diversity in the Black Sea and Characterization of the Bioluminescence Field in the Crimea neritic Zone. In: Eremeev, V.N. and Gaevskaya, A.V., Eds., The Modern Solution of Biological Diversity in Near-Shore Zone of Crimean (the Black Sea Sector), ECOSI Hydrophysics, Sevastopol, 121-151.

[21] Tokarev, Y.N., Evstigneev, P.V. and Mashukova, O.V. (2016) The Plankton Bioluminescents of the World Ocean: Biodiversity, Bioluminescence Characteristics in Norm and under Anthropogenic Impact. N. Orianda, Simferopol, 340 p.

[22] Williams, R., Piontkovski, S., Tokarev, Y., Mishonov, A. and Vladimirov, V. (1997) Data Base on Plankton Bioluminescence and Associated Parameters for the Mediterranean Sea. In: Cahill, B., Ed., Proceedings of the Ocean Data Symposium, Dublin 1997, Irish Marine Data Centre, Marine Institute, 118.

[23] Williams, R., Mishonov, A., Piontkovski, S., Tokarev, Y., Bityukov, E., et al. (1999) Intercalibration of the Bathyphotometers Salpa (Ukraine) and HIDEX (USA) in the Marmara Sea. Abstr. Papers of the Inter. Confer: Oceanography of the Eastern Mediterranean and Black Seas, Greece, 178.

[24] Evstigneev, P.V. and Bituykov, E.P. (1990) Bioluminescence of the Marine Copepods. Naukova Dumka, Kiev, $144 \mathrm{p}$.

[25] Tokarev, Yu.N., Evstigneev, P.V. and Mashukova, O.V. (2007) Bioluminescence of Plankton Organisms as an Index of the Neritic Aquatoriums Pollution. Proceedings of the 8th International Conference on the Mediterranean Coastal Environment “Medcoast 07", Alexandria, Egypt, 13-17 November 2007, Middle East Technical University, Ankara, Turkey, 2: 925-936.

[26] Piontkovski, S.A., Tokarev, Y., Bitukov, E.P., Williams, R. and Kiefer, D.A. (1997) The Bioluminescent Field of the Atlantic Ocean. Marine Ecology Progress Series, 156, 33-41. https://doi.org/10.3354/meps156033 
[27] Hickman, G.D., Edmonds, J.A. and Lynch, R.V. (1984) Laser-Induced Marine Bioluminescence Measurements and the Potential for Airborne Remote. Remote Sensing of Environment, 15, 77-89.

[28] James, E.J., Lin, C.S. and Hooper, W.P. (1998) Simulation of Laser-Induced Light Emissions from Water and Extraction of Raman Signal. Journal of Atmospheric and Oceanic Technology, 16, 394-401.

[29] Neshiba, S. (1967) Pulsed Light Stimulation of Marine Luminescence in Situ. Limnology \& Oceanography, 12, 222-235. https://doi.org/10.4319/lo.1967.12.2.0222

[30] Vasilkov, A.P. (1991) Concerning Possibility of Bioluminescence Remote Registration in the Ocean. Oceanologiya, 6, 999-1003.

[31] Bozin, S.A. and Filimonov, V.S. (1985) Spontaneus Bioluminescence of Dinoflagellates in the Vostok Bay, the Sea of Japan. Oceanology, 25, 509-512.

[32] Lyamshev, L.M. (1999) Radiation Acoustic. Sorosovsky obrazovatelny zhurnal, 6, 98-104.

[33] Miller, S.D., Haddock, S.H.D., Elvidge, C.D. and Lee, T.F. (2005) Detection of a Bioluminescent Milky Sea from Space. Proceedings of the National Academy of Sciences, 102, 14181-14184. https://doi.org/10.1073/pnas.0507253102

[34] Widder, E.A., Latz, M.J. and Case, J.F. (1983) Marine Bioluminescence Spectra Measured with an Optical Multichannel Detection System. Biological Bulletin of the Marine Biological Laboratory, Woods Hole, 163, 791-810. https://doi.org/10.2307/1541479

[35] Kopelevich, O.V., Burenkov, V.I. and Sheberstov, S.V. (2008) Case Studies of Optical Remote Sensing in the Barents Sea, Black Sea, and Caspian Sea. In: Barale, V. and Gade, M., Eds., Remote Sensing of the European Seas, Springer, Berlin, 53-66. https://doi.org/10.1007/978-1-4020-6772-3_4

Scientific Research Publishing

Submit or recommend next manuscript to SCIRP and we will provide best service for you:

Accepting pre-submission inquiries through Email, Facebook, LinkedIn, Twitter, etc. A wide selection of journals (inclusive of 9 subjects, more than 200 journals)

Providing 24-hour high-quality service

User-friendly online submission system

Fair and swift peer-review system

Efficient typesetting and proofreading procedure

Display of the result of downloads and visits, as well as the number of cited articles

Maximum dissemination of your research work

Submit your manuscript at: http://papersubmission.scirp.org/

Or contact abb@scirp.org 